\title{
The Limits of Arbitration Law in Addressing Cultural Diversity: The Example of Ismaili Arbitration in the United Kingdom
}

\author{
Sandrine Brachotte
}

Citation: Brachotte, Sandrine. 2021. The Limits of Arbitration Law in Addressing Cultural Diversity: The Example of Ismaili Arbitration in the United Kingdom. Laws 10: 47. https://doi.org/10.3390/ laws10020047

Received: 19 March 2021

Accepted: 26 May 2021

Published: 7 June 2021

Publisher's Note: MDPI stays neutral with regard to jurisdictional claims in published maps and institutional affiliations.

Copyright: (C) 2021 by the author. Licensee MDPI, Basel, Switzerland. This article is an open access article distributed under the terms and conditions of the Creative Commons Attribution (CC BY) license (https:// creativecommons.org/licenses/by/ $4.0 /)$.
Law School, Sciences Po, 75007 Paris, France; sandrine.brachotte@sciencespo.fr

\begin{abstract}
This article studies religious arbitration from the perspective of global legal pluralism, which embraces both normative plurality and cultural diversity. In this context, the article considers that UK arbitration law regulates both commercial and religious arbitration while relying on a monist conception of arbitration. It further identifies two intertwined issues regarding cultural diversity, which find their source in this monist conception. Firstly, through the study of Jivraj v. Hashwani ([2011] UKSC 40), this article shows that the governance of religious arbitration may generate a conflict between arbitration law and equality law, the avoidance of which can require sacrificing the objectives of one or the other branch of law. The Jivraj case concerned an Ismaili arbitration clause, requiring that all arbitrators be Ismaili-a clause valid under arbitration law but potentially not under employment-equality law. To avoid such conflict, the Supreme Court reduced the scope of employment-equality law, thereby excluding self-employed persons. Secondly, based on cultural studies of law, this article shows that the conception of arbitration underlying UK arbitration law is ill-suited to make sense of Ismaili arbitration. In view of these two issues, this article argues that UK arbitration law acknowledges normative multiplicity but fails to embrace the cultural diversity entangled therewith.
\end{abstract}

Keywords: global legal pluralism; cultural studies of law; religious arbitration; multiculturalism; equality rights

\section{Introduction}

In the United Kingdom (UK), as in most states, arbitration is recognised under state law as an alternative dispute resolution process, where the parties are free to apply the rules they choose, to have their disputes decided on by arbitrators they designate, and according to a procedure that they also expressly agree on, as long as they respect mandatory provisions and public policy. From the perspective of state law, such legal treatment of arbitration reflects the application of the general principle of party autonomy, associated to the freedom to contract.

Arbitration can also be studied from the perspective of "global legal pluralism", a paradigm elaborated by Paul Shiff Berman, the editor of this Special Issue. ${ }^{1}$ This paradigm combines both the recognition of the normative authority of several state and non-state actors, and the acknowledgment of the cultural diversity associated therewith. Through these lenses, arbitration can be assessed with regard to the ability of state law to recognize 'the diversity of traditions, beliefs, histories, and cultures that make up human societies.' ${ }^{2}$ In this regard, according to global legal pluralism, the state conception of arbitration must 'allow for dialogue and cooperation under conditions of diversity.' 3

Within this framework, this article focuses on religious arbitration, understood as the dispute resolution process used by some religious communities to solve internal

1 (Berman 2012). More generally, about the notion of legal pluralism that has been subject to complexified, more developed theorisations lately, given the rapidly evolving context of globalisation, see (Berman 2020); (Roughan and Halpin 2017); (Krisch 2010); (Twining 2010); (Teubner 2012).

2 See the introduction to this Special Issue.

3 Ibid. 
disagreements. ${ }^{4}$ It is further based on the observation that UK arbitration law, i.e., the 1996 Arbitration $\mathrm{Act}^{5}$, applies to both commercial and religious arbitration, without that the specificities of religious arbitration (which itself a plural concept) be taken into account. For the 1996 Arbitration Act relies on a monist (as opposed to pluralist), or uniform, conception of arbitration. In this respect, this article identifies two intertwined issues regarding cultural diversity. Firstly, it contemplates that two potentially conflicting national laws are relevant to regulate religious arbitration-namely arbitration law and equality law. Secondly, it considers that arbitration law may not be able to make sense of the rationales of some religious arbitration proceedings.

Regarding the first issue, this article considers that, at the same time as being subject to arbitration law, religious arbitration is also subject to cultural diversity-related policies, which are generally implemented through equality law and the protection of freedom of religion. ${ }^{6}$ In this second context, the religious arbitration at stake is regulated, not based on the conception of arbitration under UK law, but while having regard to the rationales of the religious community concerned, at least to a certain extent. ${ }^{7}$ Consequently, the governance of religious arbitration may generate a conflict internal to UK law, between arbitration law and equality law. The avoidance of such conflict can further require sacrificing the objectives of one or the other branch of law.

To illustrate this issue, the article studies the much-debated UK Supreme Court case Jivraj v. Hashwani ${ }^{8}$ (Jivraj), which concerned the validity of an arbitration clause requiring that all arbitrators be Ismaili, in accordance with Ismaili arbitration. The Ismaili community is a diasporic minority Muslim group that, like several other religious communities, ${ }^{9}$ has its own arbitration system to solve disputes between Ismailis in commercial, civil, and personal matters, which is governed by a living Imam, the Aga Khan. In this context, the parties to the Jivraj case, two Ismaili businessmen, had agreed on an arbitration clause requiring that all arbitrators be Ismaili. For a series of reasons that will be further explained below, the claimant brought a case before UK courts to obtain the setting aside of the religious requirement contained in the arbitration clause. Therefore, he argued that arbitrators were employees for the purpose of the application of employment-equality law and that the clause violated the prohibition of religious discrimination at hiring, pursuant to the 2003 Employment Equality Religion or Belief Regulations ${ }^{10}$ (the 2003 Regulations), replaced since then by the 2010 Equality Act ${ }^{11}$. The Supreme Court dismissed the claim, based on the ruling that arbitrators were not employees. Therefore, it reduced the scope of protection of employment-equality law to contracts involving a link of subordination, interpreted as requiring a concrete control from the employer over the employee. As a result, it excluded

4 About religious arbitration, see (Broyde 2017).

51996 c. 23.

About religious arbitration and cultural diversity-related policies in the UK, see below, a summary of the so-called "Sharia law row" (Section 3.1.1.2).

7 State laws have their own definition of religion, which can prevent them from protecting some religions. Especially, it has been shown that Western state laws tend to see religion as essentially individual (and not communal), centrally addressed to autonomy and choice (and not as the result of spiritual allegiance), and private (and not public). In this respect, about, but not limited to, Canadian law and US law, respectively, see, e.g., (Berger 2015); (Sullivan 2018).

8 [2011] UKSC 40. This case has been extensively commented on, both in arbitration law and in equality law scholarship (see below, notes no. 33 and 45; see also, non-exhaustively but mainly: (Baker and Greenwood 2012); (Oseni and Abia 2012); (Dasteel 2012). More recently, the Jivraj case has been subject matter of some theoretical analysis concerning the engagement of private international law and arbitration law with contemporary issues, including religious arbitration (Brachotte 2019); (Licari 2019); (Najjar 2019). This article belongs to this larger reflection.

9 See (Broyde 2017).

102003 no. 1660.

112010 c. 15. 
all self-employed persons from the scope of application of the 2003 Regulations (and thus also from that of the 2010 Equality Act). ${ }^{12}$

As will be further argued below, the exclusion of arbitrators from the scope of application of employment-equality law enabled the Supreme Court to avoid a conflict between the standards of arbitration law, on the one hand, and the standards of employment-equality law, on the other. Particularly, it prevented that the validity of the arbitration clause be generally subject to both the principle of party autonomy, under arbitration law, and the prohibition of religious discrimination of arbitrators, under employment-equality law. Depending on one or the other of these standards, the validity of an arbitration clause may indeed be dismissed or confirmed.

Regarding the second issue explored here, namely the difference between the UK legal conception of arbitration and the Ismaili conception of arbitration (and potentially in other religious communities' conception of the same), the article adheres to cultural studies of law. ${ }^{13}$ It thus depicts state law as a cultural artefact. In this context, the "culture" of state law must be understood as covering "founding myths", "necessary beliefs", and "reasons that are internal to legal norms". ${ }^{14}$ Thus, state norms are envisaged as being supported by foundational assumptions that are culturally situated, in contrast with the official, internal discourse about the neutrality of state law. ${ }^{15}$

Against this background, this article assumes that the conception of arbitration reflected by arbitration law is culturally situated (and not universal, nor neutral). Therefore, this article provides a comparative culturalist analysis, which shows that the conception of arbitration underlying UK arbitration law is ill-suited to make sense of Ismaili arbitration. More precisely, it will be demonstrated that UK arbitration law is unable to encompass the full significance of Ismaili arbitration because reflects a non-religious, commercial understanding of arbitration, from which Ismaili arbitration substantially differs. On one side, arbitration law envisages arbitrators as performing, for parties who pay for it, an adjudicatory service that reflects the special commercial expertise and reputation for which they have been chosen. On the other side, Ismaili arbitrators, who act on behalf of the Aga Khan, volunteer to resolve a conflict between two members of the Ismaili community (who have recourse to Ismaili arbitration to demonstrate their spiritual allegiance) for the benefit of all Ismailis and in accordance with the Ismaili ethos. As we will argue, this Ismaili conception of arbitration may lead to a different interpretation of some aspects of arbitration law, such as the principle of party autonomy that was at stake in the Jivraj case.

In view of the two issues introduced above that pertain to the monist conception of arbitration reflected by arbitration law, this article argues that UK arbitration law stands as an example of institutionalised legal pluralism that acknowledges normative multiplicity but fails to embrace the cultural diversity entangled therewith. UK arbitration law appears culturally limited in its ability to recognise and address the normative effects of some religious arbitration proceedings, which can negatively impact the navigation of cultural diversity by the state.

This argument is structured as follows. The following part of this article addresses the first issue related to the uniform conception of arbitration under UK arbitration law,

12 When, in 2010, the 2003 Regulations were incorporated into the Equality Act, which not only concerns religious discrimination but also any discrimination based on, for example, gender, race, disability, or sexual orientation, the exclusion of self-employed persons from the scope of protection of employment-equality law was extended to other discriminatory criteria than religion. Article 83(2)(a) of the 2010 Equality Act, defining the scope of application of the employment-equality law, reprises the wording of the 2003 Regulations; and, therefore, covers "contract of service or of apprenticeship or contract personally to do any work". The Supreme Court did not overturn its interpretation of "contract of service or of apprenticeship or contract personally to do any work". See, e.g., Pimlico Plumbers Ltd. and another v Smith [2018] UKSC 29; and recently, Uber BV v Aslam [2021] UKSC 5, where it appears clearly that the 2010 Equality Act has the same (limited) scope as the 1996 Employment Rights Act and thus only protects employees under a concrete link of subordination. One can note, however, that some decisions of lower courts have followed a less narrowed approach, based on the necessity either that the so-claimed "employee" is paid (see Ms F Gabe v the United Reformed Church (24 November 2017 [2017] UKET 2204367 / 2012)) or that there exist mutual obligations (amounting de facto for the employer to pay a wage (Quashie $\mathrm{v}$ Stringfellow Restaurants Ltd. [2012] EWCA Civ 1735; Windle v Secretary of State for Justice [2016] I.C.R. 721)). 
namely the possibility of conflict with equality law when religious arbitration is concerned. Therefore, it summarises the Jivraj case, while highlighting the fact that the Supreme Court's decision reduced the scope of protection of employment-equality law to avoid a conflict with arbitration law, and that this was due to the legal conception of arbitration (Section 2). Next, the article develops the second issue pertaining to the legal definition of arbitration, namely that, from a culturalist perspective, the conception of arbitration of UK law appears ill-suited to regulate Ismaili arbitration (Section 3). In view of these two issues, the conclusive part of the article summarises the argument that UK arbitration law fails to embrace the cultural diversity associated with legal pluralism (Section 4).

\section{Jivraj v. Hashwani (UK, 2011): A Conflict Avoided between Arbitration Law and Employment-Equality Law ... But at What Price?}

As mentioned in the introduction, this section summarises the Jivraj case, and considers the reduction of the scope of protection of employment-equality law that it has generated, because of the arbitration context of the dispute (and hence because of the relevance of arbitration law). Therefore, this section first explains the dispute at stake, which pertained to the validity of an Ismaili arbitration clause and led the claimant to invoke a violation of employment-equality law (Section 2.1). Second, this section outlines the Supreme Court decision about this dispute, which caused the restriction of the application of employment-equality law to contracts involving a link of subordination, exclusive of self-employment contracts (Section 2.2). Third, this section argues that this decision enabled the avoidance of a conflict between arbitration and employment-equality standards, concerning the validity of arbitration clauses. It will further highlight that this situation is due to the monist conception of arbitration under arbitration law, which is to apply to both religious and non-religious arbitration (Section 2.3).

\subsection{The Dispute: The Validity of an Ismaili Arbitration Clause and Employment-Equality Law ${ }^{16}$}

The Jivraj case involved two businessmen, members of the Ismaili community, who disagreed on whether the three arbitrators charged with solving their corporate dispute should necessarily all be Ismaili, despite the unequivocal wording of the arbitration clause.

The parties, Mr. Jivraj and Mr. Hashwani, are international hoteliers ${ }^{17}$ who, according to UK courts, were both living in London at the time of the case. ${ }^{18}$ In addition, both parties are members of the Shia Imami Ismail community (hereafter, the "Ismaili community"). There is a long-standing tradition of dispute resolution within the Ismaili community through what is commonly called "Ismaili arbitration", to which we shall return to later.

In 1981, the parties completed a joint venture agreement (the Agreement), with a view to initiate and promote investments in real estate in Canada, Pakistan, the US, and the UK. Clause 8 of the Agreement contained an arbitration clause, providing as follows:

'(1) [ ... ] any dispute difference or question shall [ . . ] be referred to three arbitrators (acting by a majority) one to be appointed by each party and the third arbitrator to be the President of the H.H. Aga Khan National Council [today the "Ismaili Centre"] for the United Kingdom for the time being. All arbitrators shall be respected members of the Ismaili community and holders of high office within the community. (2) The arbitration shall take place in London and the arbitrators' award shall be final and binding on both parties. ${ }^{19}$

Clause 9 of the Agreement further subjected the joint venture contract to UK law.

16 Unless specified otherwise below, this summary of the facts is based on the first instance judgment (Jivraj v. Hashwani [2009] 2 All ER (Comm) 778 (26 June 2009)).

17 (Zaiwalla 2011, p. 274).

18 Comp. (Zaiwalla 2011, p. 274), who argued that Mr. Hashwani was a Pakistani resident.

19 Joint Venture Agreement of 19 January 1981, Clause 8 (emphasis added). 
During the 1980s, the joint venture came to hold substantial interests in Canada, the United States, Pakistan, and the United Kingdom, by investments in properties, hotels, and the oil industry. ${ }^{20}$

In late 1988, however, a dispute arose between Mr. Jivraj and Mr. Hashwani, such that they agreed to part company. To solve the issues concerned, they submitted their dispute to two consecutive Ismaili conciliation panels, as preliminary proceedings to the enforcement of the arbitration clause mentioned above. Both proceedings partly failed, and some issues remained unsolved at the end of each proceeding. In addition, Mr. Hashwani did not accept the process followed by the second panel. According to Sarosh Zaiwalla, the lawyer acting for Mr. Hashwani, the Ismaili conciliator Mr. Ahamed grounded his assessment of the dispute on one sole expert witness's analysis, contrary to the demands of due process:

'Mr. Ahamed did not follow the usual standards required in an international arbitration in that he met both parties privately from time to time as and when he considered it necessary. Furthermore, it was left to Stoy Hayward, a Chartered Accountant firm, instructed by Mr. Jivraj, to prepare accounts for the purpose of calculating equalization payments between the joint venture partners. ${ }^{21}$

Beyond this contestation of the process itself by Mr. Hashwani, both parties agreed that two principal matters of substance remained unsolved at the end of this proceeding. On the one hand, Mr. Hashwani claimed that he was due a balance on the capital accounts. On the other hand, Mr. Jivraj argued that Mr. Hashwani had failed to pay certain tax liabilities, which exposed Mr. Jivraj to secondary liability (under UK law, as per Clause 9 of the Agreement).

The parties seem to have continued communicating on these points until $2000 .^{22}$ Between 2000 and 2008, Mr. Hashwani claimed to have tried to obtain assistance from within the Ismaili community to make Mr. Jivraj pay the monies allegedly due, without success. $^{23}$

This deadlock caused an escalation in the conflict. In 2008, Mr. Hashwani's solicitors wrote to Mr. Jivraj asserting a claim for $£ 1,412,494$ with a view to reviving the dispute resolution process, while this time activating Clause 8 of the Agreement. Therefore, $\mathrm{Mr}$. Hashwani notified the appointment of an arbitrator on his side. However, the person thus appointed, Sir Anthony Colman, a retired judge of the High Court of England and Wales, was of Jewish faith. While the Jewish community has its own system of religious arbitration, ${ }^{24}$ which resembles Ismaili arbitration, the appointed arbitrator was clearly not a member of the Ismaili community, as required by Clause 8. With respect to this appointment, Mr. Zaiwalla explained, 'Mr. Hashwani wanted at least one member of the tribunal to be a former member of the English judiciary [ . . ] to ensure that the arbitration is conducted according to the procedural standards of an English arbitration and would produce an enforceable award. ${ }^{25}$ Thus, Mr. Hashwani seemed to have lost confidence in the ability of a "purely" Ismaili arbitration panel to respect UK arbitration law, especially due process. At the same time, he may have chosen a Jewish jurist to make sure that the latter was familiar with the ethos underlying Ismaili arbitration, which shows similarities with the Jewish ethos.

When Mr. Hashwani notified Mr. Jivraj of the appointment of Mr. Colman, he called him on to appoint a second arbitrator within seven days, pursuant to Article 14(1) of the new 1996 Arbitration Act (that had just entered into force). ${ }^{26}$ Thereupon, rather than

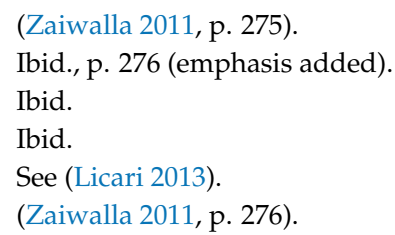

2 Pursuant to Article 84(2), the 1996 Arbitration Act applies to arbitral proceedings commenced on or after its date of entry into force, under an arbitration agreement whenever made. According to the Arbitration Act 1996 (Commencement No. 1) Order 1996, the 1996 Arbitration Act came into force on 31 January 1997. 
appoint his own arbitrator, Mr. Jivraj made an application to the English High Court seeking a declaration that the appointment of Sir Anthony Colman was invalid because the latter was not a member of the Ismaili community, as required under Clause 8 of the Agreement. Six weeks later, Mr. Hashwani issued an arbitration claim form seeking an order that Sir Anthony be appointed despite Mr. Jivraj's opposition thereto, pursuant to Article 18(2) of the 1996 Arbitration Act. These two proceedings were consolidated before the English High Court (Queen's Bench Division, Commercial Court).

Before UK courts, Mr. Hashwani contended that the Ismaili background of the arbitrators as required under Clause 8 of the Agreement constituted a religious discrimination against potential, non-Ismaili arbitrators. As we will see later, Mr. Hashwani hence invoked employment-equality law; while, according to the rationales of UK law, the validity of an arbitration clause should be examined on the basis of arbitration law. Yet, Mr. Hashwani attempted to make equality law applicable to his claim, because arbitration law could not lead the judge to take the specific meaning of Ismaili arbitration into account to decide on the case. In this context, he grounded his claim on, alternatively: (i) the 2003 Regulations; (ii) the 1998 Human Rights $\mathrm{Act}^{27}$; and (iii) UK public policy. Given that the two alternative legal grounds were set aside after the first instance, we will focus on the 2003 Regulations.

Mr. Hashwani argued that the 2003 Regulations applied to arbitrators, pursuant to Article 2(3) thereof. This provision states that the 2003 Regulations apply to "contract of service or of apprenticeship or contract personally to do any work". Arbitrators, Mr. Hashwani contended, enter that category. He also argued that the exception to the prohibition of religious discrimination in offering employment, contained in Article 7(3) of the 2003 Regulations, did not apply in the case at hand. The fulfilment of the conditions to the application of the 7(3) exception requires the demonstration that the religious requirement represents a genuine occupational requirement (GOR), which furthermore appears proportionate, having regard both to the religious ethos of the employer and to the nature of the employment. Mr. Hashwani thus claimed that these conditions were not met (for reasons that we leave out here, to focus on the most relevant issues).

In addition, Mr. Hashwani claimed that Clause 8 of the Agreement containing the arbitration clause should survive, while setting aside the invalid requirement that the arbitrators be Ismaili. In this regard, the doctrine of severance of illegal contract clauses applies. According to this doctrine, the fact that one element of the arbitration clause is void does not automatically paralyse the remainder of the provision. It only does so when the remaining unsevered parts of the arbitration clause would be substantially different from what the parties intended. ${ }^{28}$ On this point, Mr. Hashwani argued that the arbitration agreement could work perfectly well without the religious restriction. He pointed out that the third member of the tribunal would be an Ismaili in any event, as per the wording of Clause 8, which designates the President of the Ismaili Centre for the UK. ${ }^{29}$ Mr. Jivraj further remained free to choose an Ismaili arbitrator, so that only the third arbitrator would not be Ismaili.

As will be elaborated below, the examination of this claim by the judge of first instance was the beginning of a judicial controversy that led the case to the Supreme Court, the ruling of which overturned the judgment of the Court of Appeal. In fact, Mr. Hashwani's claim, however unsuccessful, caused the entire situation to spiral out of control, generating several unforeseen consequences for other communities, especially these of (non-religious) commercial arbitration and self-employment.

27 Human Rights Act 1998 , c. 42.

28 Jivraj v. Hashwani [2010] EWCA Civ 712 (22 June 2010), para. 31, referring to Marshall v NM Financial Management Ltd. [1995] 1 W.L.R. 1461, [1997] 1 WLR 1527.

29 [2010] EWCA Civ 712, op cit, para. 33. Note that Ismaili Centres are located in London, Lisbon, Toronto, Dubai, Dushanbe, and Burnaby. 


\subsection{The Supreme Court Decision: The Exclusion of Arbitrators from Employment-Equality Law ... and More}

The Jivraj case went up to the Supreme Court, and not without surprises. As a matter of fact, none of the three courts-in first instance, on appeal, and at the supreme levelgranted Mr. Hashwani's claim that the arbitration clause survived without the religious requirement attached to the appointment of arbitrators (so that he could compel Mr. Jivraj to enter arbitration proceedings where one of the arbitrators would not be Ismaili). Should the religious requirement be considered invalid, based on the doctrine of severance, the three courts agreed ${ }^{30}$ that the entire clause should be invalidated. The arbitration clause would then have a fundamentally different meaning 'from that which had originally been contemplated', given the characteristics of Ismaili arbitration. ${ }^{31}$ We will return to these characteristics below, as they indeed give Ismaili arbitration a different meaning than "arbitration" UK arbitration law.

Thus, the courts' decisions on employment-equality law did not impact the outcome of the litigation. In any case, Mr. Hashwani could not impose to Mr. Jivraj an arbitration process where one arbitrator would not be Ismaili, contrary to what he claimed. To the contrary, the courts' decision greatly mattered to third parties, namely all arbitration communities-religious or not-and, as it turned out, self-employed persons. Indeed, Mr. Hashwani's claim required from the courts that they decide whether arbitrators are employees for the purpose of the application of the 2003 Regulations. In this context, the courts had to both define a "contract of service or of apprenticeship or contract personally to do any work", as per Article 2(3) of the 2003 Regulations, and characterise the status of arbitrators under arbitration law (is there a contract between the parties and the arbitrator? If so, is the arbitrator under a link of subordination?). In addition, should the courts rule that arbitrators were employees, and that the 2003 Regulations were therefore applicable, the courts then had to decide whether, in the case at hand, the requirement that all arbitrators be Ismaili amounted to a GOR, and was thus valid, as per Article 7(3) of the 2003 Regulations.

The first instance court decided that arbitrators were not employees and thus dismissed the overall application of the 2003 Regulations (thereby finding that the arbitration clause at stake was valid). Conversely, the Court of Appeal decided that arbitrators were employees under Article 2(3) and that the religious requirement contained in the contentious arbitration clause was not justified under Article 7(3). This judgment sparked an uproar within the arbitration world, largely made of non-religious, commercial arbitration institutions, especially the renowned International Chamber of Commerce (ICC) and London Court of International Arbitration (LCIA). Standard agreements about ICC and LCIA arbitration in London include a negative condition of nationality in the appointment of arbitrators, namely that the latter should not have the same nationality as one of the parties. ${ }^{32}$ Both prominent international arbitration institutions, like several other actors of the commercial arbitration world, were therefore worried that the Court of Appeal had in

30 To be accurate, the two first courts agreed, and the Supreme Court denied ruling on this question, since it found that the religious requirement included in the arbitration clause was valid ([2011] UKSC 40, op cit, para. 72).

31 As per the first instance judgment, summarised by the Court of Appeal ([2010] EWCA Civ 712, op cit. para. 32). See also the reasoning of the Court of Appeal itself: [2010] EWCA Civ 712, op. cit., para. 34. Comp. Samuel 2010, where it is argued that even when amputated of the religious requirement, recourse to non-religious arbitration better reflects the parties' intentions than a default submission to the jurisdiction of the courts. It is striking that in developing such a reasoning, the courts followed an overtly subjectivist, and even culturalist, approach, in contrast with the regular objective standards of interpretation (on accepted modes of contractual interpretation by English courts, see (Samuel 2007, pp. 342-55); (Samuel 2010, pp. 133-42). As Lord Hoffman explained in Chartbrook Ltd. v Persimmon Homes Ltd. ([2009] UKHL 38), the terms of the contract are normally to be assessed by 'what a hypothetical reasonable objective observer, aware of all the relevant facts known to both parties, and what has been communicated between the parties, would have concluded to be their intention').

32 See International Chamber of Commerce 1998, Art. 9.1; London Court of International Arbitration 1998, Art. 6. These provisions are still in force today: see International Chamber of Commerce, Art. 13; London Court of International Arbitration 2014-2021, Art. 6. 
effect condemned such clauses under UK law, and thereby dealt a blow to London as a leading location for international arbitration..$^{33}$

Luckily enough for commercial arbitration institutions, the Supreme Court reversed this decision of the Court of Appeal and came back to the first instance assessment that arbitrators did not fall under the scope of application of the 2003 Regulations. To this end, as we will see, it interpreted Article 2(3) in a way that restricted the scope of application of the 2003 Regulations to its minimum. Concretely, the Supreme Court had to answer two questions: first, are arbitrators employees for the purpose of the application of the 2003 Regulations, according to Article 2(3), with regard both to arbitration law about the status of arbitrators, and to employment-equality law about the definition of employment (Section 2.2.1)? Second, if so, is it valid in any case to require that the arbitrators be Ismaili, as per the exception laid down in Section 7(3) of the 2003 Regulations (Section 2.2.2)?

2.2.1. Are Arbitrators Employees for the Purpose of the Application of the 2003 Regulations?

To answer the question as to whether arbitrators were under a "contract of service or of apprenticeship or contract personally to do any work", as per Article 2(3) of the 2003 Regulations, the Supreme Court had to decide on two points, namely: (a) the status of arbitrators (are they under a contract, and if so, under what kind of contract?), pertaining to arbitration law; and (b) the definition of a "contract of service or of apprenticeship or contract personally to do any work", which belongs to employment-equality law.

On point (a) about the status of arbitrators, the Supreme Court denied credit to the Court of Appeal's appreciation that arbitrators were like solicitors. Instead, it followed the first instance assessment that arbitrators should be assimilated to judges, regarding their common duty of impartiality. ${ }^{34}$ At the same time, the Supreme Court ruled that arbitrators were under a sui generis contract, in accordance with the mainstream view in international commercial arbitration. ${ }^{35}$ In this context, in line with arbitration law, the Supreme Court did not distinguish between Ismaili arbitrators and other arbitrators; however, remarkably, the former are not paid while the latter are (often generously) remunerated for their adjudicatory services.

Regarding point (b) about the definition of a "contract of service or of apprenticeship or contract personally to do any work", the Supreme Court interpreted Article 2(3) in a way that restricted the scope of application of the 2003 Regulations to the existence of a concrete link of subordination (which is the most restrictive standard to define employment). To understand this interpretation, it is useful to start from the Court of Appeal's ruling. The Court of Appeal decided that Article 2(3) covered both employment and self-employment contracts. In this respect, the Court of Appeal relied on the criterion of access to the economic market: any contract where one person hires another person within the economic market is a "contract personally to do any work". The Court attributed this broad interpretation of the notion of employment to the fact that the 2003 Regulations purported to transpose the Council Framework Directive 2000/78/EC of 27 November 2000 establishing a general framework for equal treatment in employment and occupation (called here "the Directive" or "the 2000 employment-equality Directive"). ${ }^{36}$ The Court contended that the Directive was 'concerned with discrimination affecting access to the means of economic activity, whether through employment, self-employment or some other basis of occupation $[\ldots] .^{\prime 37}$

33 Several arbitration lawyers have commented on the judgment of the Supreme Court with unconcealed relief, even so far as titling their academic contribution, published by arbitration journals, for example, "dark cloud lifted" (Chalk and Choong 2011); "the return to normality" (Dundas 2011); or, "the UK Supreme Court overturns a controversial Court of Appeal ruling" (Smith et al. 2011). Yet, this fear does not seem sound, since the proportionality of the national requirement under Article 7(3) of the 2003 Regulations is rather certain. Perhaps the arbitration world just did not want to be subject to employment-equality law at all.

34 Jivraj v. Hashwani, [2011] UKSC 40, op cit, para. 41.

35 See, e.g., (Born 2009, p. 160). See also (Fouchard et al. 1996, p. 161).

36 Official Journal L 303, 2 December 2000, pp. 16-22.

37 [2010] EWCA Civ 712, op cit, para. 15. 
Ignoring the criterion of access to the economic market followed by the Court of Appeal, the Supreme Court ruled that the 2003 Regulations only applied to employment contracts in the strict sense of the term, i.e., in contracts involving a link of subordination, interpreted as requiring a concrete control from the employer over the employee. In this respect, the Supreme Court agreed with the Court of Appeal that the 2003 Regulations should be construed in accordance with the Directive. Yet, it interpreted the scope of the Directive differently than the Court of Appeal because, ultimately, it disagreed with the Court of Appeal on the principles of interpretation of EU law (which there is no space to further discuss here). As a result, the Supreme Court decided that the definition of a "contract personally to do any work" should be aligned with the notion of "worker" used in Article 141 of the Treaty establishing the European Community. ${ }^{38}$ This provision requires equal pay for male and female workers (and thus constitutes a prohibition of discrimination based on gender in the realm of employment). According to Allonby $v$ Accrington \& Rossendale College (hereafter, Allonby) ${ }^{39}$, under Article 141, a "worker" is 'a person who, for a certain period of time, performs services for and under the direction of another person in return for which [she] receives remuneration. ${ }^{40}$ This definition refers to the criterion of subordination as concrete control, and accordingly, in the Supreme Court's opinion, so too should the definition of a "contract personally to do the work" that establishes the scope of application of the 2003 Regulations, do.

In view of these two findings (about the status of arbitrators and about the definition of employment regarding equality rights), the Supreme Court ruled that arbitrators were not under a "contract of service or of apprenticeship or contract personally to do any work", as per Article 2(3) of the 2003 Regulations. They were under a sui generis contract that did not involve a link of subordination between the arbitrators and the parties. Such a link of subordination would prevent the arbitrators to decide on the dispute impartially.

2.2.2. If Arbitrators Are Employees, Is It Valid in Any Case to Require That the Arbitrators Be Ismaili?

After having determined whether arbitrators were employees (Article 2(3)), the Supreme Court alternatively examined whether it was proportionate to the Ismaili ethos to require that the arbitrators be Ismailis, as per Article 7(3) of the 2003 Regulations. As mentioned earlier, the application of the 7(3) exception requires the demonstration that the religious requirement represents a genuine occupational requirement (GOR), which furthermore appears proportionate, having regard both to the religious ethos of the employer and to the nature of the employment.

In assessing the applicability of this exception in the Jivraj case, the Supreme Court observed that 'Ismaili arbitrators may well be best placed to assess the nature of each party's conduct, in circumstances when they all subscribe to the same moral and ethical codes as promulgated by their Imam, His Highness the Aga Khan. ${ }^{41}$ This seems to highlight the idea that the proceedings, or what could perhaps be called the procedural attitudes of religious arbitrators, are in themselves important to the parties irrespective of the applicable law. As will be shown below, this indeed seems to rightly reflect the Ismaili conception of intra-community arbitration.

Hence, the Supreme Court found that, even if arbitrators would fall under the scope of application of the 2003 Regulations, the religious requirement concerning arbitrators that was included in the arbitration clause at stake was valid, pursuant to the Article 7(3) exception. With regard to the specificities of Ismaili arbitration, the Court ruled that this religious requirement did not constitute a religious discrimination at hiring, because it was a GOR, proportionate to the Ismaili ethos of the parties (the employer) and to the nature of

\footnotetext{
38 Treaty establishing the European Community (EC Treaty) Official Journal C 325, 24 December 2002, pp. 33-184 (consolidated version 2002), today replaced by the Treaty on the Functioning of the European Union (TFUE) Official Journal C 202, 7 June 2016, pp. 47-201 (consolidated version 2016).

39 (Case C-256/01) (2004) ICR 1328.

40 [2011] UKSC 40, op cit, paras. 67-68 (emphasis added).

41 Ibid., para. 70.
} 
the arbitrators' roles in Ismaili arbitration (the employment). Thus, in the context of the application of employment-equality law, it is visible that the Supreme Court considered the specifics of Ismaili arbitration, contrary to the reasoning that it followed to apply arbitration law, where the religious meaning of the arbitration proceedings at stake did not gave to (and perhaps could noy) be granted any legal weight.

\subsection{An Assessment of the Courts' Decisions: The Price of Saving the Face of Arbitration Law}

This section argues that that the Supreme Court's decision summarised above enabled the avoidance of a conflict between arbitration and employment-equality standards, concerning the validity of the arbitration clause; however, at the cost of excluding selfemployed persons from the scope of protection of the 2003 Regulations (today the 2010 Equality Act). It further argues that this outcome is due to the monist conception of arbitration under arbitration law. To make this argument, it shows how, by contrast, the adoption of a culturalist reasoning in the context of arbitration law, which acknowledges the plurality of conceptions of arbitration, could have led to overcoming this pitfall.

To develop this argument, this section will first explain the conflict between arbitration law and employment-equality at stake and show how the limitation of the application of the 2003 Regulations to employment contracts in the strict sense of the term was a way to avoid such conflict, given the monist conception of arbitration. Thereafter, it will demonstrate that this limitation of the 2003 Regulations could have been prevented, should arbitration law allow courts to consider the specific meaning of Ismaili arbitration, in accordance with a culture-based, or culturalist, reasoning beyond the monist conception of arbitration. Such reasoning entails the application of the relevant legal rules, while having regard to the cultural particularities involved, which the common interpretation of the legal rules concerned may not permit to contemplate. ${ }^{42}$

First of all, it is contended here that the Supreme Court's decision to place arbitrators outside of the scope of application stopped an overlap between employment-equality law and arbitration law. Why so? Pursuant to arbitration law, Article 1(b) of the 1996 Arbitration $\mathrm{Act}^{43}$ that protects the pillar principle of party autonomy under arbitration law, is to govern the question of the validity of an arbitration clause. According thereto, any arbitration agreement must be respected by the parties unless it is contrary to the public interest. "The public interest" covers two types of rules. On the one hand, the matter subject to arbitration must be arbitrable; and, on the other hand, the arbitration agreement must respect mandatory provisions of UK law that safeguard the arbitrators' duties of fairness and impartiality, especially Article 33 of the 1996 Arbitration Act. ${ }^{44}$ The question of the religious discrimination of arbitrators is thus not part of "the public interest". As a result, had the Supreme Court decided that the validity of the arbitration clause was subject to employment-equality law, it would have submitted one question-the validity of arbitration clause - to two conflicting national regulations, namely: arbitration law (about party autonomy within the limits imposed by "the public interest"); and employmentequality law (about the prohibition of religious discrimination at hiring, unless the religious belonging of the potential employee is a GOR under Article 7(3) (or meets the conditions of the other few exceptions provided by the 2003 Regulations)).

Expectedly, the Supreme Court decision was criticised amongst equality and employment rights defenders for unduly reducing the scope of protection of employmentequality law, which, they contended, was meant to apply to both employment and self-

42 The notion of culturalist reasoning is mostly discussed in the context of criminal proceedings, where defendants sometimes adopt a culturalist defense (see, e.g., Good 2008); (Foblets and Renteln 2009); see also, the consideration of culture in legal reasoning regarding Indigenous ontologies in (Hamilton 2009).

431996 c. 23.

44 (Cleobury and Style 2011, pp. 570-71), referring to the DAC Report (Departmental Advisory Committee on Arbitration 1996, para. 155). 
employment contracts. ${ }^{45}$ In this respect, it must be conceded that the interpretation of the 2000 employment-equality Directive by the Supreme Court can easily appear upsetting, irrespective of who, between the Court of Appeal and the Supreme Court, applied the principles of interpretation of EU law correctly. While the reasoning of the Supreme Court referring to the notion of "worker" may seem sound at first sight, it does not stand up to the basic principle followed in both EU law and UK law, according to which the scope of protection offered under employment-equality law purports to be broader than the one provided under the rest of employment law. In view thereof, the interpretation by the Court of Appeal of a link of subordination as merely requiring an economic dependence (and not also a concrete control) seems more appropriate. That way, a clear and effective objective can further be associated to the Directive, i.e., providing equal access to the market economy for all. In addition, this interpretation has the merit of respecting the wording of Article 3 of the Directive that states its scope of application and does not speak of "workers" but of "conditions for access to employment, self-employment and occupation." In this respect, the official interpretation of the Directive by the EU is anyway unequivocal: "The directive applies to all individuals, whether they are working in the public or private sectors, in relation to: conditions of access to employed or self-employed activities. ${ }^{46}$

The argument made here is that the decision of the Supreme Court to (hence unjustly) reduce the scope of the 2003 Regulations, in order to avoid a conflict with arbitration law, is due to the monist conception of arbitration associated with the latter. To understand this, it can be observed that, conversely, the Supreme Court could have avoided restricting the scope of protection offered by the 2003 Regulations, had it been allowed by arbitration law to define the status of Ismaili arbitrators differently from the status of other arbitrators, based on the consideration of the specific features of Ismaili arbitration, thereby adopting a culturalist reasoning. This culturalist reasoning could have been followed in the Jivraj case, in two ways.

Firstly, the Supreme Court could have considered that, differently from commercial arbitrators (who are the standard arbitrators under arbitration law, Ismaili arbitrators are not paid. As will be further explained in the next section, this is because the role of Ismaili arbitrators differs from that of non-religious commercial arbitrators. On that basis, it could have limited the scope of its ruling to Ismaili arbitrators specifically. Thus, the Supreme Court could have followed the economic definition of the link subordination of the Court of Appeal, and yet excluded Ismaili arbitrators from the scope application of the 2003 Regulations (since they are not paid!).

Secondly, the Supreme Court could have avoided restricting the scope of protection offered by the 2003 Regulations under a culturalist reasoning, because this reasoning could have dissuaded Mr. Hashwani from invoking the 2003 Regulations in the first place (thereby sparing the courts from having to adjudicate between employment-equality law and arbitration law). In fact, according to the rationales of UK law, the 2003 Regulations were clearly not meant to be invoked in the Jivraj case, to the extent that it concerns a dispute between two potential employers. Instead, the 2003 Regulations (today the 2010 Equality Act) were designed to protect employees and to enable them to claim more rights

45 See, e.g., (Connolly 2013); (Freedland and Kountouris 2012). The discontent of equality rights defenders and the self-employed could be even greater given that, as mentioned above (note no. 12), in 2010 the 2003 Regulations were incorporated to the Equality Act, which not only concerns religious discrimination but also any discrimination based on, for example, gender, race, disability, or sexual orientation.

46 See, among the official summaries of EU law on the EU website: https://eur-lex.europa.eu/legal-content/EN/TXT/?uri=LEGISSUM\%3Ac10823, accessed 25 May 2021. 
against employers. ${ }^{47}$ Yet, Mr. Hashwani relied on the 2003 Regulations, for reasons of legal strategy. As highlighted just above, he could only lose his case based on Article 1(b) of the 1996 Arbitration Act (i.e., the normally applicable standard to assess the validity of the arbitration clause in the Jivraj case, according to the rationales of UK law).

In contrast, a culturalist reasoning about Article 1(b) could have led the courts to assess the validity of the arbitration clause by considering the specific context of Ismaili arbitration, and consequently take Mr. Hashwani's claim more seriously. As mentioned above, Article 1(b) of the 1996 Arbitration Act provides that an arbitration clause is invalid if it is contrary to the public interest, which includes the arbitrators' duties of fairness and impartiality. Commonly, the impartiality and fairness of arbitrators is assessed regarding both the arbitrators' concrete behaviour and several objective circumstances. ${ }^{48}$ Such assessment is further made by reference to the practice of (non-religious) international commercial arbitration (we will come back to this in the next section).

Alternatively, following a culturalist reasoning in the Jivraj case, the courts could have considered the communal and spiritual dimensions of Ismaili arbitration to assess Ismaili arbitrators' fairness and impartiality, and the principle of party autonomy more generally. As will be further detailed below, in the Ismaili community the recourse to internal arbitration reflects the parties' allegiances to the Aga Khan, who is deemed represented by the arbitrators, as well as the parties' identification to the Ismaili community, which is built on a strong sense of collective trust. In view of these dimensions, the notions of impartiality and party autonomy may have usefully been interpreted in a more collective (and less individualistic) way. In this context, the courts could have potentially observed that Mr. Hashwani had lost confidence in the ability of a "pure" Ismaili arbitration process to be conducted impartially, irrespective of the arbitrators involved. Indeed, on the one hand, as we have seen, before appointing a non-Ismaili arbitrator Mr. Hashwani claimed to have tried to obtain assistance from within the Ismaili community to make Mr. Jivraj pay the monies allegedly due, without success. On the other hand, he clearly expressed the view that Mr. Ahamed, an Ismaili arbitrator-conciliator who had been appointed by the parties to help them solve their dispute, not only failed to do so, but acted without respecting due process. In view of these circumstances, the courts could have decided that the religious requirement contained in the arbitration clause was not valid, in accordance with Article 1(b) of the 1996 Arbitration Act.

In any case, it remains that, pursuant to the doctrine of severance, the courts would have discarded the entire validity of the arbitration clause anyway, and thus reach the same concrete decision about the parties' claims as they did in the Jivraj case. Yet, in the meantime, the courts would have followed a legal reasoning that is better connected to the issue at hand, and that would have relieved self-employed persons from being affected by a judgment that does not concern them at all.

These research findings lead us to turn to the second issue related to the unique conception of arbitration vehiculated by arbitration law, which is intertwined with the first issue discussed here. This second issue, which becomes visible in the light of cultural studies of law, pertains to the fundamental differences that exist between the meaning of arbitration under UK arbitration law and Ismaili law, respectively.

47 In that respect, Article 9(3) of the 2010 Equality Act-in which Article 7 of the 2003 has been consolidated-makes this very clear: once the claimant has established that she has suffered a disadvantage on the grounds of religion, the burden of proof shifts to the employer to show that the occupational requirement under complaint can be justified. In addition, the 2003 Regulations included a Part V about "enforcement", which signals clearly that the 2003 Regulations were to be used to support employees' claims before employment tribunals only. Aside from this, an external observer could be surprised that employment-equality law can be invoked to protect potential employees who do not identify with a religion or identify with a majority religion, and not only potential employees who identify with a minority religion (such as Ismailism (as far as the UK is concerned)). Yet, the 2003 Regulations (and today the 2010 Equality Act) are deemed to be protecting both potential employees of a certain religion (irrespective of whether this religion is a majority or a minority religion in the country) and potential employees without a religion (Equality and Human Rights Commission 2011, para. 2.50).

48 For an overview, see, e.g., (Born 2009, chp. 13). 


\section{A Culturalist Analysis of Arbitration Law: The Differences between UK Law Arbitration and Ismaili Arbitration}

The analysis of the Jivraj case in the previous section showed that, in the context of religious arbitration, arbitration law can have negative impacts on employment equality law because of the monist conception of arbitration that it reflects (and because of the non-culturalist court reasoning that comes with it).

This section addresses a second issue related to this unique conception of arbitration, namely that UK arbitration law may be unable to make sense of a series of conceptions of arbitration. In this regard, keeping the example of Ismaili arbitration at stake in the Jivraj case, this section will show that "arbitration" according to UK arbitration law substantially differs from "arbitration" under Ismaili law. Therefore, taking the perspective of global legal pluralism endorsed here, and with the help of cultural studies of law, it proposes a culturalist comparison between the conceptions of arbitration under UK law and Ismaili law, respectively, while bearing in mind the risk of essentialisation that the exercise involves. Such comparison reflects both the normative multiplicity and the cultural diversity involved in the paradigm of global pluralism. Hence, on the one hand, regarding normative multiplicity, this comparative analysis envisages both UK law and Ismaili law as independent-although interacting — sources of normativity. On the other hand, regarding cultural diversity, this analysis assumes that the conception of arbitration under UK and Ismaili law, respectively, and the rules that reflect it, are justified by culturally situated rationales and foundational assumptions. These conceptions may therefore be very different, even if they concern the same term.

As will be further detailed below, this comparative study shows that UK arbitration law reflects the foundational assumptions and subsequent conceptions of international commercial arbitration, where the arbitration process is viewed as meeting private, transnational, mercantile interests, and is conceived as being independent from any religious ethos. In contrast, Ismaili arbitration in commercial affairs reflects the Ismaili ethos, as well as the diasporic commitment of the community, which is characterised by a hybrid identity made of both the Ismaili Muslim identity and the various national identities of the Ismailis. Consequently, the Ismaili arbitration proceedings reflect collective, state, and religious interests.

As we will also see, with respect to the issues involved in the Jivraj case discussed in the previous section (Section 2.3), the culturalist comparison explains why Ismaili arbitrators are not paid, while non-religious commercial arbitrators are remunerated. The comparison also shows that the motivations of the parties to recourse to Ismaili arbitration, like the parties did in the Jivraj case, are likely to reflect collective, spiritual interests. This stands in contrast with the willingness of businesspeople and companies to submit their dispute to commercial arbitration, which often mirrors an individualistic desire to benefit from an efficient and politically neutral dispute resolution process. In view of this difference, Ismaili arbitrators' fairness and impartiality, as limits to party autonomy, may meaningfully be assessed, by regarding the communal context of the dispute, which is absent from (or at least, not as strong in) commercial arbitration. This difference may also more generally lead to conceive an agreement to arbitrate (and party autonomy) differently, depending on whether this agreement reflects a communal spiritual allegiance (in Ismaili arbitration) or an individual sense of business instead (in commercial arbitration).

The details of this comparative analysis are provided below, starting with UK law (Section 3.1) before turning to the specifics of Ismaili arbitration (Section 3.2).

\subsection{UK Arbitration Law: International Commercial Arbitration and Secularism}

Under this culturalist analysis of UK law, it is noteworthy that UK arbitration law reflects a specific conception of arbitration (Section 3.1.2) that relies on the commercial origin and secular assumption of UK arbitration law (Section 3.1.1). 
3.1.1. Cultural Context: The Commercial Origin of UK Arbitration Law and the Principle of Secularism

To understand the conception of arbitration reflected by the 1996 Arbitration Act, it is relevant to note that UK arbitration law originates in the regulation of a dispute resolution mechanism for European merchants (Section 3.1.1.1). It is also worth indicating that the mainstream conception of arbitration reflects a secular understanding of commercial arbitration (Section 3.1.1.2).

3.1.1.1. UK Arbitration Law: The Regulation of a Dispute Resolution Mechanism for European Merchants

The United Kingdom was one of the first states to regulate arbitration, in $1698 .{ }^{49}$ Until then, the development and regulation of arbitration had remained fully in the hands of the European merchant community, which placed itself deliberately beyond the reach of both the King and the Church. ${ }^{50}$ Hence, regulating arbitration was a way for state officials to gain control over merchant communities, in order to establish the authority of modern law: if arbitration is regulated by law, it can be represented as deriving its normative authority from law, and to the extent granted by law. ${ }^{51}$ Several subsequent legal reforms reinforced the binding force of arbitration, and the development of the contemporary legal framework for commercial arbitration took place during the early 20th century, ${ }^{52}$ with the enactment of the 1889 Arbitration Act. A stable arbitration regime ensued for 45 years, subject to several amendments over time. In that context, the UK became a significant centre for international commercial arbitration, ${ }^{53}$ and UK arbitration law evolved accordingly. The current legislation in force is the above-mentioned 1996 Arbitration Act. It is thus unsurprising that the 1996 Arbitration Act does not consider religious arbitration specifically and treats it like commercial arbitration.

3.1.1.2. The Sharia Law Row-An Assumed Separation between Commercial Arbitration and Religious (Deemed Non-Commercial) Arbitration

To understand the conception of arbitration that is associated with UK arbitration law, compared to Ismaili arbitration, it is worth looking at the doctrinal debates that have surrounded the so-called "Sharia law row". In this context, it appeared clear that the mainstream legal community does not envisage religious arbitration as concerning commercial matters (which is, after all, coherent with the origin of arbitration law summarised above, given that European merchants described themselves as being detached from both the King and the Church). In other words, the mainstream legal conception of arbitration in the UK is not only concerned with commercial arbitration, but it also understands the latter as being separated from religion, and from the related national policies concerning cultural diversity.

Here, we are interested in the literature that followed the Archbishop of Canterbury Rowan Williams's lecture in 2008. Rowan Williams advocated, notably, for the recognition of religious "supplementary jurisdictions" in the UK. ${ }^{54}$ What is striking in some of these reactions is that religious arbitration is considered as something cultural, which must be subject to domestic regulation. Meanwhile, commercial arbitration is envisagedalthough mainly implicitly — as related to the globalised economic market, which, in both geographical and political terms, is deemed beyond the reach of nation states. The scholars concerned do not seem to envisage that religious arbitration can concern disputes directly related to the globalised economic market, as was the case in the Jivraj case.

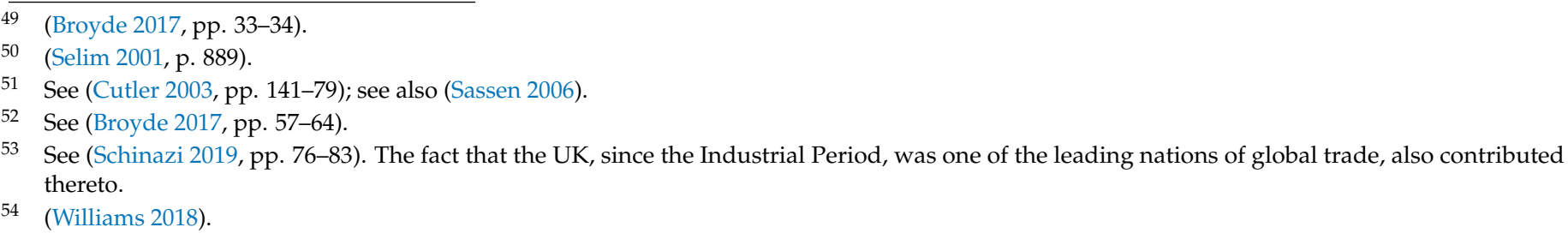


Notably, one author, British professor Brian Turner, is opposed to religious arbitration because, in the long term, this kind of private justice would supposedly diminish state sovereignty (and state "authority and coherence") and erodes citizenship 'as a social, cultural and political framework. ${ }^{55}$ In this respect, Turner asserts that both a strong state and a strong sense of citizenship are necessary to 'sustain legal pluralism, multiculturalism, and participatory citizenship', given 'the dominance of the market over both state and civil society' and 'neoliberal globalisation and financial deregulation. ${ }^{56}$ Following that logic, it seems that commercial arbitration is not at stake when it comes to the preservation of state sovereignty and citizenship. What is more, this seems to justify the state limitation of religious abitration's normative authority.

\subsubsection{A Conception of Arbitration in Line with the Cultural Context}

Because of the commercial origin of arbitration and the deemed secular character of commercial arbitration, the default standards applied to arbitration in the UK reflect the principles of international commercial arbitration, developed by national courts, arbitral tribunals and institutions, and prominent arbitration scholars. They further mirror the rationales of the commercial parties when choosing arbitration, as officially imagined within the arbitration world and by arbitration lawmakers. An examination of these rationales can be divided into two subjects, namely, the substance of these rationales (Section 3.1.2.1) and the fact that they refer to individual, private interests (Section 3.1.2.2).

\subsubsection{The Consideration of Trade Usages, Cultural Neutrality, and Material Efficiency (Political Neutrality)}

According to a mainstream official discourse among arbitration scholars, businesspeople today decide to subject their dispute to arbitration for several reasons, including the consideration of trade usages to clear the disagreement. Such usages reflect their own normative commitments and are at the same time deemed the most adapted to the industry in question. These parties may be willing to apply state law while allowing the arbitrators to take trade usages into consideration besides, ${ }^{57}$ or they may wish to solve their dispute solely according to the so-called lex mercatoria, as allowed by Section 46 of the 1996 Arbitration Act. ${ }^{58}$

Additionally, arbitration scholars praise the cultural and political neutrality of commercial arbitration. The principle of neutrality of commercial arbitration means both neutrality from politics and neutrality from cultural differences (based on the assumption that it is indeed possible to separate from these elements in a dispute resolution process). ${ }^{59}$ As far as cultural neutrality is concerned, in cases where the parties are familiar with distinct legal cultures (as is typically the case if they reside in different states), the principle of neutrality aims to avoid the arbitrators favouring one of these cultures, for instance because they are nationals of the state in question and thus naturally examine cases through its lens. This objective explains the ICC rule of negative nationality mentioned above (see Section 2.2).

As far as political neutrality is concerned, it is part of the mainstream self-narrative of commercial arbitration that businesspeople have recourse to arbitration to solve their dispute because they can do so in an efficient way, understood in very material terms. As Gary Born explains, the notion of "efficiency" in that context refers to several expected characteristics of the arbitration process:

55 (Tuner 2011, p. 326). Comp. (Hunter-Henin 2020), where it is argued that religious diversity and freedom are a driving force to contemporary Western democracies.

56 (Tuner 2011, pp. 326-27).

57 See, e.g., Article 21(2) of the ICC Arbitration Rules (International Chamber of Commerce 2017): ‘The arbitral tribunal shall take account of the provisions of the contract, if any, between the parties and of any relevant trade usages.' This duty applies irrespective of the choice of law of the parties as per Article 21(1).

58 Briefly, lex mercatoria, as it is referred to today, is a non-state law that covers current norms of business behaviour, which are general or specific to one business area. For further details, see, e.g., (Cuniberti 2015).

59 See (Hassani 2021). 
'[B]usinesses perceive international arbitration as providing a neutral, speedy and expert dispute resolution process, largely subject to the parties' control, in a single, centralized forum, with internationally-enforceable dispute resolution agreements and decisions. ${ }^{60}$

Bernardo Cremades further argues that ' $[w]$ hen businessmen sign an arbitration agreement, they are hoping for efficiency, for a way of minimising costs and risks ... nothing more!' ${ }^{\prime 1}$ Taniguchi proceeds in the same direction when he asserts that '[c]ommercial arbitration handles disputes among businessmen or business corporations. They are practical people, more concerned with efficiency than theory, more with money than ideals. ${ }^{\prime 62}$

\subsubsection{A Resolution of Conflicts in the Individual Interests of the Parties}

Given the objectives of arbitration summarised in the previous section, the commercial arbitration process is seen as meeting the interests of the parties. In this respect, and in view of comparing commercial arbitration with Ismaili arbitration, it is noticeable that the amicable resolution of conflict, dearly valued in Ismaili arbitration, is not crucial. In fact, the facilitation of amicable settlement was largely attractive in the historical context of international arbitration, ${ }^{63}$ and, even then, it related to the purpose of efficiency as it was mostly perceived as a cost-saving device.

In this context, commercial arbitrators provide a service to the parties of the dispute. They are called upon by reason of their specific commercial expertise and reputation, which is to be remunerated. Similarly, commercial arbitration institutions, like the ICC and the LCIA that were encountered in the study of the Jivraj case, are chosen by the parties to arbitrate, depending largely on their marketable reputation and expertise.

\subsection{Ismaili Arbitration: Dispute Resolution as Collective, Spiritual, and Multiple-State Allegiance}

In this section, we will see that the commercial conception of arbitration underpinning UK arbitration law, as well as the secular assumption of commercial arbitration associated thereto, are very distinct from the features of Ismaili arbitration. To do so, we will describe the Ismaili conception of arbitration (Section 3.1.2), which relies on religious-holistic but hybridised-worldviews ${ }^{64}$ (Section 3.1.1).

\subsubsection{Cultural Context: Religious, Holistic, and Hybridised Worldviews}

The official Ismaili conception of arbitration reflects a holistic spirituality (Section 3.2.1.1), which is hybridised (and thereby pluralised) to reflect the various national identities of the members of this diasporic community (Section 3.2.1.2).

3.2.1.1. Religious, Holistic Worldviews: The Aga Khan as Sole Guide, and the Concept of Coreligionist Commerce

Official Ismaili worldviews are not only religious (because they are based on the existence of a divine authority) but also holistic: they penetrate all aspects of life and these aspects are then conceived as being the reflection of one another. The status of the Aga Khan and the concept of coreligionist commerce constitute two illustrations of this phenomenon that help understanding this holistic character.

First, it seems that the living Imam of the Ismailis, called the Aga Khan, is to Ismailis a priest, a head of state, a legislator, an intellectual, and a leading economist all at the same time. His religious, political, and legal stances appear part of one another. In this context,

60 In (Born 2009), Gary Born points out that these objectives do not always match reality. For instance, arbitration proceedings are not always less costly and speedier than litigation; this depends both on arbitration processes and on the forum concerned, amongst other things.

61 (Cremades 1996, p. 17).

62 (Taniguchi 1996, pp. 38-39).

63 (Born 2009, p. 88).

64 This term is here used in accordance with (Geertz 1957). 
the current Aga Khan has notably adopted the 1986 Ismaili Constitution ${ }^{65}$ (that replaced the 1905 Constitution), which codified constitutional norms reflecting the Ismaili ethos, as well as the hybrid identity of the Ismaili community, described in the next section.

Second, concerning the concept of coreligionist commerce, since the 15th century, the Ismailis have been depicted as having developed a very efficient communitarian organisation and seem to have remarkable individual business successes among their members. ${ }^{66}$ In addition, much of this business was undertaken by associations of Ismailis, which is called "coreligionist commerce". ${ }^{67}$ According to Helfand and Richman, coreligionist commerce refers to 'commercial dealings that take place between coreligionists who intend their transactions to achieve both commercial and religious objectives. ${ }^{68}$ This reflects the official Ismaili worldviews, according to which legal, commercial, and spiritual thoughts form just one integrated way of conceiving the world. The influence of religious values on commercial conduct therefore occurs directly and naturally. ${ }^{69}$

It is striking that the concept of coreligionist commerce contrasts with the secular assumptions associated to commercial arbitration under UK law (see above, Section 3.1.1). On the one hand, the concept of coreligionist commerce is at odds with the conception of commerce of the medieval Europeans merchants, which has preceded the enactment of UK arbitration law and involved a strict separation between commercial affairs (in the hands of merchants) and religious affairs (directed by the Church). ${ }^{70}$ On the other hand, the concept of coreligionist commerce contradicts the assumption, mainstreamed in the Sharia law row, that religious arbitration, deemed national and citizenship-related, and commercial arbitration, deemed transnational and market-related, are separated in practice, with religious arbitration being limited to family matters (at the exclusion of commercial matters).

\subsubsection{Hybrid Worldviews: The Diasporic Character of the Ismaili Community}

The religious holistic worldview supporting Ismaili arbitration does not prevent it from also reflecting the diasporic character of the Ismaili community, i.e., that Ismailis are Ismailis, but that they also are citizens of various countries. The Ismailis today are indeed a transnational people, living across Asia, Middle East, Sub-Saharan Africa, and Europe and North America. ${ }^{71}$ Essentially, the diaspora retains specific cultural practices, while allowing extensive adaptation to the local community. This can be seen as the result of a process of hybridisation, involving an internalisation of the tension between "home and abroad": the place of residence and the place from which migration has occurred. ${ }^{72}$

The diasporic character of the Ismaili community is reflected by several features. Firstly, it is mirrored by the applicable in Ismaili arbitration On the one hand, Article 15 of the Ismaili Constitution provides that Ismaili arbitral tribunals (see below) can apply Ismaili personal law where this speaks to the issues at play and does not conflict with state law. On the other hand, the Constitution remains silent on the law to be applied when commercial issues are at stake, as in the Jivraj case. It was confirmed by a judicially appointed expert, representative of the Ismaili arbitration system, that Ismaili commercial

65 The official English text is available on the website of The Heritage Society, the Ismaili electronic database and library: http://ismaili.net/Source/ extra1.html, last accessed 25 May 2021.

66 (Penrad 2008, pp. 126, 131, 133).

67 As is the case in Jewish communities (see, e.g., (Licari 2013); (Berman 1971)).

68 (Helfand and Richman 2015, p. 771).

69 To be sure, there is no negative connotation here.

70 In this regard, Paul Valadier speaks of the «anormalité chrétienne» («Christian abnormality»). This abnormal distinction, in Christianism, between Cesar and God, states and churches, politics and religion(s), he explains, lies in the foundational texts. However, he argues that such distinction is hypocritical. In practice, the poles of the distinction are in constant relation, for the first reason that society and religion are strongly intertwined (Valadier 2007, pp. 162-63). Valadier further argues that the Christian distinction between the religious power and the secular or "the temporal" power ("le pouvoir religieux ( $l^{\prime}$ Eglise) et le pouvoir temporel ( $\left.l^{\prime} E t a t\right)$ ") is reflected in the way law addresses religious issues in Western countries, whereas Islam 'does not fit well' within such separation (Ibid., p. 132).

71 (Jamal 2013, p. 236).

72 (Kalra et al. 2005, pp. 72-73). 
transactions are governed by the relevant state law(s). ${ }^{73}$ Yet, the "Ismaili ethos" is always intended to guide the dispute resolution process.

Secondly, as a political leader of the Ismaili community, the Aga Khan has been and still is an important figure for Western states, in line with the hybrid Ismaili identity. The current Aga Khan, who received a Western education, ${ }^{74}$ is a well-respected political leader among Western heads of state, especially in Canada, the US, and the UK, where he is considered to have played 'a significant role in socio-political and cultural issues of the contemporary world ${ }^{75}$, not only for the Ismailis, but also for the rest of the society. In this respect, the current Aga Khan promotes a cosmopolitan-here meaning "able to be reconfigured to new contexts" ${ }^{\prime 76}$ —open, and pluralist Islam.

In the next section, we will see that these Ismaili hybrid worldviews justify that specific features of the arbitration process are sought by Ismaili parties (below, Section 3.2.2.1) which are distinct from the characteristics of commercial arbitration that are expected by businesspeople and companies (above, Section 3.1.2.1).

\subsubsection{A Conception of Arbitration in Line with the Cultural Context}

Having described the Ismailis' worldviews, we are now in a better position to understand Ismaili arbitration. Ismaili arbitration can however mean different things depending on time and place. Historically called Tahkim, Ismaili arbitration dates back to the time when there was no centralised, established system of justice. It was promoted by the Prophet Muhammad, and thus became much practiced. ${ }^{77}$ However, it has evolved over time, and today is officially represented worldwide by the Conciliation and Arbitration Boards (CAB) system, established by the above-mentioned 1986 Ismaili Constitution. The $\mathrm{CAB}$ system is organised like a judicial national pyramid, but at the transnational level: there are regional (or local) and national CABs, as well as an International Conciliation and Arbitration Board (ICAB). A local Board arbitral award can be appealed before the national Board (NCAB) that has jurisdiction, the decision of which can itself be appealed before the ICAB. ${ }^{78}$ When elements of the dispute belong to several local CABs, the competent NCAB hears the case in first instance. NCABs have been set up in most countries where there are significant Ismaili settlements-i.e., nineteen jurisdictions to date ${ }^{79}$-and all local CABs are attached thereto. Finally, the ICAB directly renders awards on cases that involve Ismailis who fall under the jurisdiction of distinct NCABs. Hence, differently from commercial arbitration that counts several arbitration institutions among which businesspeople and corporations can choose, Ismaili arbitration is centralised around one transnational, hierarchical dispute resolution system. This difference, one may argue, can constitute another reason to interpret the principle of party autonomy distinctively, depending on the Ismaili or (non-religious) commercial context of the arbitration at stake.

This CAB system replaced, in a spirit of continuity, the Ismaili Councils and Tribunals that had been performing a judicial role for the Ismailis for many decades. ${ }^{80}$ The arbitration

73 Shan MOMIN (Executive Officer, Aga Khan International Conciliation and Arbitration Board), email message 4 December 2019. When a CAB dispute in commercial matters involves parties belonging to distinct states, the applicable law will be chosen by the parties, and, in the absence of such agreement, the arbitrators will have to undertake a conflict of laws analysis to figure out the closest connection to the dispute (Shan MOMIN (Executive Officer, Aga Khan International Conciliation and Arbitration Board), email message 1 March 2021).

74 (Dewji 2018, p. 79).

75 Ibid., p. 3.

76 (Leonard 2009, p. 177).

77 (Born 2009, pp. 52-53). The Prophet's references to arbitration were aimed principally at replacing the pagan arbitrators of the pre-Islamic period, whereby an arbitrator was chosen by the parties of the dispute, usually the priest of the pagan cult, who claimed to have supernatural powers of divination (Saleh 2006).

78 See Articles 12 and 13 of the Ismaili Constitution (http:/ / ismaili.net/Source/extra1.html, last accessed 25 May 2021).

79 These jurisdictions are: Afghanistan, Australia, Canada, Congo, Dubai, France, India, Iran, Kenya, Madagascar, Pakistan, Portugal, Syria, Tajikistan, Tanzania, Uganda, UK, USA, and recently Mozambique.

80 See National Conciliation and Arbitration Board for the United Kingdom, The Rules for Arbitration Proceedings in the United Kingdom, London, 22 May 2010 (unpublished). Preamble, paras. C and E. This document was sent by a representative of the Ismaili community (Shan MOMIN (Executive Officer, Aga Khan International Conciliation and Arbitration Board), email 4 December 2019). However, these arbitration rules are not in force anymore; they were superseded by the ICAB 2015 arbitration rules (discussed below), which apply to all CABs around the world. 
clause in the Jivraj case was signed in 1981, i.e., before the adoption of the Constitution. Yet, the latter text is arguably relevant for the understanding of the case because it purports only to approximate or harmonise pre-existing practices and does not create fundamentally new rules. In addition, the courts relied on the Constitution in the Jivraj case. ${ }^{81}$

Thus, we can examine the general, official rationales that lead Ismailis to submit their disputes to Ismaili arbitration based on the 1986 Constitution. In symmetry with the study of commercial arbitration above, this section distinguishes between the substance of these rationales (Section 3.2.2.1) and the fact that they refer to communal interests, namely those of the Ismaili community taken as a whole (Section 3.2.2.2).

\subsubsection{Ismaili Arbitration to Reflect the Parties' Spiritual Allegiance and Their Diasporic Belonging}

In accordance with the Ismaili worldviews described above, the CAB system (or its predecessor, the Councils and Tribunals) should be the main dispute resolution mechanism available to Ismailis when they encounter a disagreement among themselves. ${ }^{82}$ One may note that such a mainstream, "normal" character of arbitration does not exist (yet), at least at such a level, in commercial arbitration. ${ }^{83}$

This conception of Ismaili arbitration reflects the rationale that, by submitting their disputes to Ismaili arbitrators, Ismaili show their spiritual allegiance and belonging to the Ismaili community. On the one hand, the spiritual allegiance is satisfied by the fact that the $\mathrm{CAB}$ and ICAB arbitrators are appointed by the Aga Khan. ${ }^{84}$ On the other hand, as mentioned above, Ismaili arbitration is the one forum where the double belonging to the Ismaili community and to various nation states is reflected. Even when states laws must govern the merits of the case (as is the case in commercial matters), the arbitrators must decide on the case while observing the Ismaili ethos, as detailed in the next section. Therefore, $\mathrm{CAB}$ and ICAB arbitrators are trained on the Islamic ethical underpinnings of alternative dispute resolution, i.e., the Ismaili ethos, and arbitral panels are usually chaired by a lawyer who is well versed in arbitration proceedings, and who ensures that the work of the $\mathrm{CAB}$ is conducted within the framework of applicable national laws. ${ }^{85}$ Furthermore, even if this was not the case yet at the time of the drafting of the arbitration clause between Mr. Hashwani and Mr. Jivraj, the Ismaili arbitration rules that were adopted later limit the choice of the parties regarding the arbitrators, who are generally selected by the $C A B$ on behalf of the Aga Khan. ${ }^{86}$ In view of this, and in view of the mainstream character of arbitration, one may want again to assess the principle of party autonomy of arbitration law-discussed in the Jivraj case-differently.

It must be further highlighted that these two objectives-the demonstration of spiritual allegiance and the consideration of the double belonging of Ismailis-are very distinct from the aims of consideration of trade usages, cultural neutrality, and material efficiency (in commercial arbitration), as reasons to submit a dispute to arbitration. In particular, the objective of cultural neutrality of commercial arbitration directly opposes the objective of Ismaili arbitration of reflecting the diasporic identity of the community, i.e., its attachment to both the common religious identity and the various national identities of its members. As

81 [2011] UKSC 40, op cit, para. 65.

82 However, "main" does not mean "compulsory": Ismailis must bring their case voluntarily before the CAB.

83 Although, some authors have advocated for international commercial arbitration to become the default mode of resolution of conflicts amongst parties domiciled in different states (see, e.g., (Cuniberti 2017)).

84 (Keshavjee 2006, p. 83); [2011] UKSC 40, op cit, Witness Statement of Noordin Nanji, paras. 4.3, 6.15, 7.5.

85 [2011] UKSC 40, op cit, Witness Statement of Noordin Nanji, para. 4.6.

86 Hence, Article 6.2 of the 2015 arbitration rules provide that ' $\mathrm{CAB}$ will select the arbitrators from its list of potential arbitrators and will seek the Parties' input. Specifically, CAB will provide each Party with a list of five names, along with short biographies, of potential arbitrators. The Parties will have 5 business days to deliver to $C A B$ a ranking, from 1-5, of their respective preferences of potential arbitrators, which will inform, but not bind, CAB's final decision in forming the Arbitral Tribunal.' See His Highness Prince Aga Khan, Shia Imami Ismaili Conciliation and Arbitration Board Arbitration Rules (unpublished, sent by and asserted to be in force since 2015 by Shan Momin, Executive Officer of the ICAB, in an email 20 February 2020), hereafter "2015 ICAB arbitration rules". These arbitration rules apply to all CABs' arbitration proceedings since 2015 (and thus replaced any NCAB arbitration rules, such as these of the UK NCAB-see above, note no. 80). 
was just mentioned, the Ismaili Constitution expressly provides for the consideration of the national law(s) of the parties. To the contrary, in commercial arbitration, the consideration of the national laws and legal cultures of the parties is limited as much as possible, as shown by the aforementioned ICC rule expressly allowing the prohibition of designating arbitrators who have the same nationality as one of the parties. As for the consideration of trade usages and the material efficiency of the proceedings, these are given space in the more recent Ismaili arbitration rules, ${ }^{87}$ however, it is still clear that the respect for the Ismaili ethos throughout the proceedings, as well as the respect for the relevant national laws, are granted the most importance.

\subsubsection{A Resolution of Conflicts for the Peace of the Ismaili Community: The Ismaili Ethos}

In contrast with the individual interests involved in commercial arbitration proceedings (see above), it is striking that the Ismaili arbitration process first and foremost aims at protecting collective interests, namely those of the Ismaili community, taken as a whole. Again, this may lead to conceiving the principle of party autonomy of arbitration law differently. Indeed, this principle, itself based on the freedom to contract, reflects the universalist, liberal ideal of the rational, autonomous individual who freely takes decisions. ${ }^{88}$ This vision hardly appears appropriate to make sense of the communal stakes involved in Ismaili arbitration.

These collective stakes, however, are crucial. This is indeed where the Ismaili ethos takes its full significance. The Ismaili ethos refers to the need to keep the Ismaili community at peace. Therefore, any dispute resolution process should aim at an amicable resolution of conflict, which, if it cannot lead the parties to conciliate their views, should at least be reflected by the arbitration process, to foster a deep and long-term reconciliation between the parties, by not exacerbating any adversity aimed at winning the case. Such reconciliation is meant to benefit the Ismaili community beyond the parties of the dispute.

The amicable resolution of disputes is provided by the Qur'an (IV:31). ${ }^{89}$ The voluntary and peaceful resolution of conflicts is further embedded in the teachings and practice of the Muslim tradition..$^{90}$ As explained by the former Chairman of the ICAB:

'[T]he broader Muslim tradition, and specifically the Shia Ismaili Muslim tradition, defines and fosters an ethos for amicable dispute resolution that, unlike the "secular" litigation culture, is non-adversarial. [ ... ] The community is in effect a stakeholder in the amicable resolution of the dispute. [ ... ] The community seek to resolve the dispute in an amicable manner in order to minimize any potential repercussions of that resolution both on the parties themselves and on others who may be affected' ${ }^{91}$

In these perspectives, not only are Ismaili arbitrators trained in the amicable resolution of conflicts, but they also act as volunteers who abide by the Ismaili ethos. They are not paid by the parties, ${ }^{92}$ as they perform the task of arbitrator for the sake of their faith, which

87 On the one hand, Article 1.3. of the 2015 Arbitration Rules (see note no. 86 associates the Ismaili values of 'unity, brotherhood, justice, tolerance, equity and good will' to an arbitration process that is 'fair, efficient, cost-effective, final and binding'. This association reflects the endorsement of what one may call an "ethical efficiency". On the other hand, the 2015 Arbitration Rules officially grant priority to the parties' choice over the applicable law. In this context, the parties can choose that the lex mercatoria applies instead of the relevant national law(s) (see Article 11.2). Yet the arbitration rules do not provide that, irrespective of the applicable law, the arbitrators may consider relevant trade usage (as is the case of the ICC arbitrations rules-see above, note no. 98). Instead, what Ismaili arbitrators must always consider, even in commercial matters, is the Ismaili ethos, which requires an amicable resolution of the conflict for the benefit of the entire Ismaili community. In this regard, (see, e.g., (Chernilo 2013)).

89 Quran 4:131.

90 [2011] UKSC 40, op cit, Witness Statement of Noordin Nanji, para. 6.1.

91 Ibid., paras. 6.12 and 6.16 (emphasis added).

92 It must be said that the whole arbitration process is not completely free of cost. Article 13.1 of the 2015 ICAB Arbitration Rules (see above, note no. 86) provides that ' $[t]$ he Parties will be required to pay a fee to cover the costs of the arbitration (including administrative fees, travel expenses, and costs engaged by independent experts engaged by the tribunal).' Hence, while arbitration is a gratuitous act done to the benefit of the whole community, this obviously does not involve the arbitrators personally shouldering the burden of the costs of proceedings. 
carries a collective dimension, i.e., that of helping other members of the community to resolve their conflict so that everybody can live in peace. This of course places Ismaili arbitrators in a quite different position than commercial arbitrators stands as another justification of the absence of remuneration of Ismaili arbitrators, contrary to the monetary rights of commercial arbitrators.

\section{Concluding Reflections: Arbitration and the Navigation of Cultural Diversity}

In the previous sections, we have first argued that disregarding Ismaili specificities under arbitration law can place UK courts in a situation where they may sacrifice the objective of some other law to safeguard the rationales of arbitration law, which correspond to those of the commercial arbitration world. This is what happened in the Jivraj case analysed above: avoiding a conflict between arbitration law and employment-equality law, the Supreme Court rendered a judgment that excluded any kind of arbitrators from the scope of application of employment-equality law. Therefore, it defined the relationship of subordination as being limited to concrete control, thereby dismissing the criterion of economic dependence, by which self-employed persons (and not only employees in the strict sense of the term) would be protected by the 2003 Regulations. This seems unfortunate, not only for self-employed persons, but also given the objective, present both at the EU and UK levels, of managing cultural diversity. As it transposed the 2000 employment-equality Directive, we have seen that the 2003 Regulations aimed at ensuring an equal access to work - and the social and material benefits that come with it-for people of all faiths. In this context, it does not seem legally correct to exclude self-employed persons.

This article has further shown that UK arbitration law was unable to encompass the full significance of Ismaili arbitration, especially when defining the status of arbitrators, arbitrators' duties of fairness and impartiality as a limit to party autonomy, and the principle of party autonomy more generally, which were at stake in the Jivraj case. This is because, as the comparative culturalist analysis has demonstrated, UK arbitration law reflects a monist conception of arbitration that corresponds to commercial arbitration, from which Ismaili arbitration substantially differs. On the one hand, arbitration law envisages arbitrators as performing, for parties who pay for it, an adjudicatory service that reflects the special commercial expertise and reputation for which they have been chosen. In contrast, Ismaili arbitrators, acting on behalf of the Aga Khan who select them among Ismailis, volunteer to resolve a conflict between two members of the Ismaili community (who have recourse to Ismaili arbitration to demonstrate their spiritual allegiance) for the benefit of all Ismailis and in accordance with the Ismaili ethos. In addition, Ismaili arbitration in commercial matters reflects the widespread practice, among Jewish and Muslim communities, of coreligionist commerce. We have seen that this practice is at odds with the Western, secular understanding of commerce which is reflected in UK arbitration law, because the latter assumes that commercial arbitration corresponds to economic interests that are distinct from religious allegiance. Religious allegiance is associated to religious arbitration instead, which is deemed relating to personal and family matters (and not commercial matters), as illustrated by the Sharia law row debate.

In view of the combination of these two studies-of the Jivraj case and of Ismaili arbitration-UK arbitration law appears as an example of institutionalised legal pluralism that acknowledges normative multiplicity but fails to embrace the cultural diversity entangled therewith. UK arbitration law appears culturally limited in its ability to recognise and address the normative effects of some religious arbitration proceedings, which can negatively impact the navigation of cultural diversity by the state. In addition, as the analysis of the Jivraj case has shown, UK arbitration law can further limit the management of cultural diversity indirectly, by leading to the reduction of the scope of application of employment-equality law.

This argument may lead to thinking about some directions for reform. At first glance, it seems that a distinct legal treatment of commercial and religious arbitration would be 
beneficial to many, i.e., state courts (and ultimately states), the self-employed, commercial arbitrators, Ismaili arbitrators, and other kinds of arbitrators. De lege ferenda, it is conceivable that religious arbitration be subject to a distinct legal regime. Yet, this could lead to at least one questionable outcome, namely that the religious arbitration systems attached to distinct religions would be treated as being alike, whereas religions may share different conceptions of arbitration.

Therefore, alternatively and de lege lata, the adoption of culturalist reasonings by state courts could be more appropriate. Under the analysis of the Jivraj case above (Section 2.3), we have suggested some avenues of culturalist reasoning that could have prevented the Supreme Court from deciding on Mr. Hashwani and Mr. Jivraj's dispute, by excluding self-employed persons from the protection of employment-equality law. At the end of the day, the more general adoption by UK courts of a culturalist reasoning when confronted to religious arbitration seems feasible. On the one hand, it is a general trend that domestic courts in Europe use culturalist considerations to reflect the pluralisation of the society. ${ }^{93}$ On the other hand, this is precisely what the Court of Appeal (and the first instance judge) have done in the Jivraj case, when they have applied the doctrine of severance that pertains to contract law. As mentioned above, the Court of Appeal denied the survival of the arbitration clause without the religious requirement (that the arbitrators appointed by the parties be Ismaili), given the specific meaning of Ismaili arbitration.

Aside from these proposals of legal reforms or changes in legal reasoning, this concluding part points to the insights of the culturalist stance endorsed in this article, regarding the general theorisation of arbitration law, as reflected by the 1996 Arbitration Act and the principles of international commercial arbitration attached thereto. Notably, it leads to challenge the legal official depiction of commercial arbitration as a purely economic, non-political, and non-religious type of arbitration. This article has shown that arbitration law can negatively impact the navigation of cultural diversity both directly (by not granting any legal space to some conceptions of arbitration, like the Ismaili one) and indirectly (by reducing the scope of protection of cultural diversity by other laws). It also leads to challenge the legal conception of commercial arbitration, however historically justified, as separated from issues of citizenship, sovereignty, and politics in general.

Funding: This research received no external funding.

Institutional Review Board Statement: Not applicable.

Informed Consent Statement: Not applicable.

Data Availability Statement: Data sharing not applicable.

Acknowledgments: The author thanks the Laura Bassi Foundation for the scholarship awarded to edit this work. The author also thanks Horatia Muir Watt and Jacco Bomhoff for their unvaluable comments at earlier stages of the drafting of this article.

Conflicts of Interest: The author declares no conflict of interest.

\section{References}

Assier Andrieu, Louis. 1996. Le droit dans les sociétés humaines. Paris: Nathan.

Baker, C. Mark, and Lucy Greenwood. 2012. The Regionalisation of International Arbitration: Maintaining International Standards in

Appointing Arbitrators-A Comment on Jivraj v Hashwani. In The Practice of Arbitration-Essays in Honour of Hans van Houtte.

Edited by Patrick Wautelet, Thalia Kruger and Govert Koppens. Oxford: Hart Publishing, pp. 15-23.

Berger, Benjamin. 2015. Law's Religion. Religious Difference and the Claims of Constitutionalism. Toronto: University of Toronto Press.

Berman, Mildred. 1971. The Location of The Diamond-Cutting Industry. Annals of the Association of American Geographers 61: 316-28.

[CrossRef]

Berman, Paul Schiff. 2012. Global Legal Pluralism: A Jurisprudence of Law Beyond Borders. New York: Cambridge University Press.

Berman, Paul Schiff, ed. 2020. The Oxford Handbook of Global Legal Pluralism. New York: Oxford University Press.

Born, Gary. 2009. International Commercial Arbitration, 3rd ed. Alphen aan der Rijn: Kluwer Law International.

93 On this question, (see, e.g., Foblets and Vetters 2020). 
Brachotte, Sandrine. 2019. Intermingled rationalities: Using private international law to deal with 'unsolvable' cases? In Global Private International Law. Edited by Muir Watt Horatia, Diego Fernandez Arroyo, Lucia Bizikova and Agatha Brandão De Oliveira. Cheltenham: Edward Elgar Publishing, pp. 190-201.

Broyde, Michael J. 2017. Sharia Tribunals, Rabbinical Courts and Christian Panels. Religious Arbitration in America and in the West. Oxford: Oxford University Press.

Chalk, Richard, and John Choong. 2011. Dark Cloud Lifted: Jivraj v Hashwani. Asian Dispute Review 13: 121-22.

Chernilo, Daniel. 2013. The Natural Law Foundations of Modern Social Theory: A Quest for Universalism. Cambridge: Cambridge University Press.

Cleobury, Philomena, and Christopher Style. 2011. Jivraj v. Hashwani: Public Interest and Party Autonomy. Arbitration International 27: $563-73$.

Connolly, Michael. 2013. Jivraj v Hashwani. EMP LB 113: 3-5.

Coombe, Rosemary. 2001. Is there a Cultural Studies of Law? In A Companion to Cultural Studies. Edited by Miller Toby. Oxford: Blackwell, pp. 36-62.

Cremades, Bernardo. 1996. Introductory Remarks: International Dispute Resolution-Towards an International Arbitration Culture. In International Dispute Resolution: Towards an International Arbitration Culture. Edited by Jan Van Den Berg Albert. The Hague, London and Brussels: Kluwer Law International.

Cuniberti, Gilles. 2015. Three Theories of Lex Mercatoria. Columbia Journal of Transnational Law 52: 369-434.

Cuniberti, Gilles. 2017. Rethinking International Commercial Arbitration: Towards Default Arbitration. Cheltenham: Edward Elgar.

Cutler, Claire. 2003. Private Power and Global Authority: Transnational Merchant Law in the Global Political Economy. Oxford: Oxford University Press.

Dasteel, Jeff. 2012. Arbitration Agreements That Discriminate in the Appointment and Selection of Arbitrators. Richmond Journal of Global Law \& Business 11: 383-405.

Dewji, Sahir. 2018. The Aga Khan's Discourse of Applied Pluralism: Converging the "Religious" and the "Secular". Studies in Religion/Sciences Religieuses 47: 78-106. [CrossRef]

Dundas, Hew R. 2011. The return of normality: The UK Supreme Court decides Jivraj. Arbitration 77: 467-73.

Foblets, Marie Claire, and Alison Dundes Renteln. 2009. Multicultural Jurisprudence: Comparative Perspectives on the Cultural Defence. Oxford: Hart Publishing.

Foblets, Marie-Claire, and Larissa Vetters. 2020. The pluralization of European societies and the role of the judiciary. In Justice and Culture: Theory and Practice Concerning the Use of Culture in Courtrooms. Edited by Ríos Vega Luis Efrén, Ilenia Ruggiu and Irene Spigno. Napoli: Editoriale Scientifica, pp. 77-98.

Fouchard, Philippe, Emmanuel Gaillard, and Berthold Goldman. 1996. Traité de l'arbitrage Commercial International. Oxford: Oxford University Press.

Freedland, Mark, and Nicola Kountouris. 2012. Employment equality and personal work relations-A critique of Jivraj v. Hashwani. Industrial Law Journal 41: 56-66. [CrossRef]

Geertz, Clifford. 1957. Ethos, World-View, and the Analysis of Sacred Symbols. The Antioch Review 17: 621-37. [CrossRef]

Geertz, Clifford. 1983. Local Knowledge. Further Essays in Interpretive Anthropology. London: Fontana Press.

Good, Anthony. 2008. Cultural Evidence in Courts of Law. The Journal of the Royal Anthropological Institute 14: 47-60. [CrossRef]

Hamilton, Jennifer. 2009. Indigeneity in the Courtroom Law, Culture, and the Production of Difference in North American Courts. New York: Routledge.

Hassani, Amina. 2021. La Neutralité de l'arbitrage International, Essai de Déconstruction d'un Mythe. Ph.D. dissertation, Sciences Po School of Law, Paris, France.

Helfand, Michael A., and Barak D. Richman. 2015. The Challenge of Co-religionist Commerce. Duke Law Journal 64: 769-822.

Hunter-Henin, Myriam. 2020. Why Religious Freedom Matters for Democracy-Comparative Reflections from Britain and France for a Democratic "Vivre Ensemble". Oxford: Hart Publishing.

Jamal, Arif A. 2013. Religious Authority and Constitutional Order: A case study of the Conciliation and Arbitration Boards (CABs) of the Shia Imami Ismaili Community. Journal of Law, Religion \& State 2: 235-49.

Kahn, Paul. 1999. The Cultural Study of Law: Reconstructing Legal Scholarship. Chicago and London: The University of Chicago Press.

Kalra, Virinder S., Raminder Kaur, and John Hutnyk. 2005. Diaspora E Hybridity. London: Sage.

Keshavjee, Mohamed M. 2006. Alternative Dispute Resolution in a Muslim Community: The Shia Imami Ismaili Conciliation and Arbitration Board. In Migration, Diasporas and Legal Systems in Europe. Edited by Shah Prakash and Werner Menski. Oxford and New York: Routledge-Cavendish, pp. 73-85.

Knox, Sarah L., and Cristyn Davies. 2013. The Force of Meaning. Cultural Studies of Law. Cultural Studies 27: 1-10. [CrossRef]

Krisch, Nico. 2010. Beyond Constitutionalism: The Pluralist Structure of Postnational Law. Oxford: Oxford University Press.

Leonard, Karen. 2009. Transnational and Cosmopolitan Forms of Islam in the West. Harvard Middle Eastern and Islamic Review 8: 176-99.

Licari, François-Xavier. 2013. L'arbitrage rabbinique entre droit talmudique et droit des nations. Revue de l'arbitrage 1: 57-120.

Licari, François-Xavier. 2019. Beyond legal pluralism: Some thoughts on paideic arbitration. In Global Private International Law. Edited by Muir Watt Horatia, Diego Fernandez Arroyo, Lucia Bizikova and Agatha Brandão De Oliveira. Cheltenham: Edward Elgar Publishing, pp. 182-90. 
Marissal, Amélie, and Charles Reveillere. 2020. Les cultures juridiques à l'épreuve de l'enquête. Présentation du dossier. Droit et Société 105: 277-88. [CrossRef]

Najjar, Nathalie. 2019. Religious identity: Between non-discrimination and party autonomy. In Global Private International Law. Edited by Muir Watt Horatia, Diego Fernandez Arroyo, Lucia Bizikova and Agatha Brandão De Oliveira. Cheltenham: Edward Elgar Publishing, pp. 201-12.

Oseni, U. Umar Aimhanosi, and Kadouf Hunud Abia. 2012. The Discrimination Conundrum in the Appointment of Arbitrators in International Arbitration. Journal of International Arbitration 29: 519-44.

Penrad, Jean-Claude. 2008. Identités Disséminées: Musulmans d'origines indopakistanaises en Afrique orientale. Lusotopie 15: 125-40. [CrossRef]

Roughan, Nicole, and Andrew Halpin, eds. 2017. Pursuit of Pluralist Jurisprudence. Cambridge: Cambridge University Press.

Saleh, Samir. 2006. Commercial Arbitration in the Arab Middle East Shari'a, Syria, Lebanon, and Egypt, 2nd ed. Oxford: Hart Publishing.

Samuel, Geoffrey. 2007. Contract Law: Cases and Materials. London: Sweet \& Maxwell.

Samuel, Geoffrey. 2010. Law of Obligations. Cheltenham: Edward Elgar Publishing.

Sassen, Saskia. 2006. Territory, Authority, Rights: From Medieval to Global Assemblages. Princeton: Princeton University Press.

Schinazi, Mikaël. 2019. The Three Ages of International Commercial Arbitration: Between Renewal and Anxiety. Ph.D. dissertation, Sciences Po School of Law, Paris, France.

Selim, Jahel. 2001. Droit des affaires et religions. Revue Internationale de Droit Comparé 53: 879-910.

Smith, Richard, Angeline Welsh, and Manish Aggarwal. 2011. Jivraj v Hashwani-the UK Supreme Court overturns a controversial Court of Appeal ruling on arbitration clauses. International Arbitration Law Review 14: 35-39.

Sullivan, Winnifred F. 2018. The Impossibility of Religious Freedom, 2nd ed. Princeton: Princeton University Press.

Taniguchi, Yasuhei. 1996. Is There a Growing International Arbitration Culture? An Observation from Asia. In International Dispute Resolution: Towards an International Arbitration Culture. Edited by Jan Van Den Berg Albert. The Hague, London and Brussels: Kluwer Law International.

Teubner, Gunther. 2012. Constitutional Fragments: Societal Constitutionalism in Globalization. Oxford: Oxford University Press.

Tuner, Bryan S. 2011. Legal Pluralism, State Sovereignty, and Citizenship. Democracy and Security 7: 317-37. [CrossRef]

Twining, William. 2010. Normative and Legal Pluralism: A Global Perspective. Duke Journal of Comparative E International Law 20: 473-518.

Valadier, Paul. 2007. Détresse du Politique, Force du Religieux. Paris: Seuil.

Williams, Rowan. 2018. Civil and Religious Law in England: A Religious Perspective, Foundation Lecture at the Royal Courts of Justice, Archbishop of Canterbury. Available online: http:/ / www.archbishopofcanterbury.org (accessed on 7 February 2020).

Zaiwalla, Sarosh. 2011. Are Arbitrators Not Human? Are They from Mars? Why Should Arbitrators be a Separate Species? Journal of International Arbitration 28: 273-82. 